J. Clin. Chem. Clin. Biochem.

Vol. 28, 1990, pp. 505-511

(C) 1990 Walter de Gruyter \& Co. Berlin · New York

\title{
Determination of Glucose Turnover and Glucose Oxidation Rates in Man with Stable Isotope Tracers
}

\author{
By H. Reinauer, F. A. Gries, A. Hübinger, O. Knode, K. Severing and F. Susanto \\ Diabetes-Forschungsinstitut, Heinrich-Heine-Universität, Düsseldorf
}

(Received August 15, 1989//February 7/May 30, 1990)

\begin{abstract}
Summary: Determination of the turnover rates of glucose gives a more dynamic view of carbohydrate metabolism. Using ${ }^{2} \mathrm{H}$ - or ${ }^{13} \mathrm{C}$-labelled glucose, stable isotope methods have been established which are free of risk for volunteers or patients and are in accordance with the legal requirements for radiation protection. The aim of the present study was to determine the main parameters of glucose turnover in vivo by using two stable-isotope-labelled glucose molecules, $\left[6,6-{ }^{2} \mathrm{H}\right]$ glucose and $\left[\mathrm{U}-{ }^{13} \mathrm{C}\right]$ glucose. Under steady state conditions, the following parameters were analysed: glucose turnover rate, glucose oxidation rate, recycling of glucose, hepatic glucose production rate, and glucose clearance. In healthy volunteers the following data were obtained for the glucose turnover rate: $2.42 \pm 0.11 \mathrm{mg} / \mathrm{kg} \times \mathrm{min}$, glucose oxidation rate $1.34 \pm 0.08 \mathrm{mg} / \mathrm{kg} \times \mathrm{min}$, glucose clearance $3.04 \pm 0.17 \mathrm{ml} / \mathrm{kg} \times \mathrm{min}$, and glucose recycling $24.7 \%$ (about $0.6 \mathrm{mg} / \mathrm{kg} \times \mathrm{min}$ ). Under conditions of the euglycaemic-hyperinsulinaemic clamp (insulin levels about $80 \mathrm{mU} / \mathrm{l}$ ) the glucose turnover rate increased to $9-10 \mathrm{mg} / \mathrm{kg} \times \mathrm{min}$, and the hepatic glucose production rate was totally suppressed. Under these conditions identical glucose turnover rates were measured by rate of appearance $R_{a}$ and euglycaemichyperinsulinaemic clamp.
\end{abstract}

These data clearly demonstrate that by using differentially labelled glucose molecules at least five parameters of glucose metabolism may be determined in vivo. High insulin levels $(70-80 \mathrm{mU} / \mathrm{l})$ stimulate glucose turnover rate by $300-400 \%$, and the glucose infusion rate agrees well with the rate of appearance $\left(R_{a}\right)$ of glucose, determined with $\left[6,6-{ }^{2} \mathrm{H}\right]$ glucose. Thus, this glucose tracer provides relevant and presumably accurate data under basal and under hyperinsulinaemic conditions.

\section{Introduction}

The determination of glucose, lipid, and amino acid turnover in metabolic diseases gives more information about the metabolic situation than the analysis of substrate concentrations, which represent static parameters of metabolism only. The determination of the glucose disposal rate has been performed with the clamp technique (1). However, by definition, this technique does not allow the measurement of basal glucose turnover. Furthermore, under these special metabolic conditions, unreliable data may be produced unless the hepatic glucose production rate is determined simultaneously $(1-6)$. The use of radioactive tracers in medical research is subject to legal restric- tions. For this reason, glucose turnover in man has to be measured by the use of stable isotopes and isotope-dilution methods.

Different tracers have been applied for the analysis of glucose turnover rates, and $\left[6,6-^{2} \mathrm{H}\right]$ glucose has been shown to be a useful substrate for this purpose. The glucose oxidation rate can be determined with [U- ${ }^{13} \mathrm{C}$ ]glucose $(8,9,11-15)$. These and other stableisotope-labelled glucose molecules have been used in various turnover measurements in healthy volunteers and in patients, and differing results have been attributed to variations in the type and pattern of the glucose labelling (see tab. 1). 
Tab. 1. Glucose turnover rates under basal conditions by use of differently labelled glucose. The differences in turnover rates are assumed to be generated by the tracers and/or different test conditions (see text).

\begin{tabular}{|c|c|c|c|}
\hline Volunteers & Tracer & $\begin{array}{l}\mathrm{R}_{\mathrm{a}} \\
\mathrm{mg} / \mathrm{kg} \times \min \end{array}$ & References \\
\hline $\begin{array}{l}\text { Healthy volunteers } \\
24 \pm 3 \text { years } \\
\mathrm{n}=28\end{array}$ & $\begin{array}{l}{\left[6,6-{ }^{2} \mathrm{H}\right] \text { glucose }} \\
\left(\mathrm{U}-{ }^{13} \mathrm{C}\right] \text { glucose }\end{array}$ & $\begin{array}{l}2.41 \pm 0.06 \\
2.15 \pm 0.09\end{array}$ & 23 \\
\hline $\begin{array}{l}\text { Healthy volunteers } \\
52 \pm 2 \text { years } \\
n=5\end{array}$ & {$\left[3-{ }^{3} \mathrm{H}\right]$ glucose } & 2.17 & 23 \\
\hline $\begin{array}{l}\text { Healthy volunteers } \\
36.5 \pm 3.3 \text { years }\end{array}$ & $\begin{array}{l}{\left[3-{ }^{3} \mathrm{H}\right] \text { glucose }} \\
{\left[2-{ }^{3} \mathrm{H}\right] \text { glucose }} \\
{\left[6-{ }^{14} \mathrm{C}\right] \text { glucose }}\end{array}$ & $\begin{array}{l}2.1 \pm 0.1 \\
2.7 \pm 0.1 \\
2.3 \pm 0.1\end{array}$ & 27 \\
\hline $\begin{array}{l}\text { Healthy volunteers } \\
28 \pm 4 \text { years } \\
n=6\end{array}$ & $\begin{array}{l}{\left[6,6-{ }^{2} \mathrm{H}\right] \text { glucose }} \\
{\left[6-{ }^{-3} \mathrm{H}\right] \text { glucose }} \\
{\left[6-{ }^{14} \mathrm{C}\right] \text { glucose }}\end{array}$ & $\begin{array}{l}2.0 \pm 0.2 \\
2.2 \pm 0.1 \\
2.3 \pm 0.1\end{array}$ & 26 \\
\hline $\begin{array}{l}\text { Healthy volunteers } \\
24 \pm 5 \text { years } \\
\mathrm{n}=12, \mathrm{n}=4\end{array}$ & $\begin{array}{l}{\left[6,6-{ }^{2} \mathrm{H}\right] \text { glucose }} \\
{\left[\mathrm{U}-{ }^{13} \mathrm{C}\right] \text { glucose }}\end{array}$ & $\begin{array}{l}2.42 \pm 0.11 \\
1.82 \pm 0.03\end{array}$ & own results \\
\hline
\end{tabular}

The aim of the present study was to determine glucose turnover rates under basal and hyperinsulinaemic (euglycaemic-hyperinsulinaemic clamp) conditions. Besides total glucose disposal rates, the rates of glucose oxidation, glucose recycling and the hepatic glucose production rates were also measured. Two kinds of labelled glucose were used in these studies: [6,6$\left.{ }^{2} \mathrm{H}\right]$ glucose and $\left[\mathrm{U}^{-13} \mathrm{C}\right] \mathrm{glucose}$. The data from these studies will serve as basal values for the determination of glucose turnover rates in insulin resistant patients.

\section{Materials and Methods}

\section{Materials}

$\left[\mathrm{U}-{ }^{13} \mathrm{C}\right]$ glucose (purity $99 \%$ ), $\left[6,6-{ }^{2} \mathrm{H}\right]$ glucose (purity $98 \%$ ) and $\mathrm{NaH}^{13} \mathrm{CO}_{3}$ (purity $99 \%$ ) were obtained from Cambridge Isotope Laboratories, Woburn, Ma.

Insulin, human (Velasulin human) $40 \mathrm{U} / \mathrm{ml}$ was from Nordisk, Gentofte, Denmark. Glucose solution, $20 \%$ was from Dubernhard Hospital GmbH, München.

\section{Methods}

\section{Equipment}

Finnigan MAT mass spectrometer $112 \mathrm{~S}$; Finnigan MAT mass spectrometer Incos 50; Isotope ratio mass spectrometer IRMS Typ "Delta" (Finnigan) with autosampler (Gilson Sample Changer 222); Gas chromatograph (Siemens L 350) with FID and gas chromatograph Sichromat 3 with FID.

\section{Analytical techniques}

Glucose was analysed by the hexokinase/glucose-6-phosphatedehydrogenase method. In addition, glucose concentration was determined by isotope dilution/mass spectrometry $(16,17)$. On average, the isotope dilution/mass spectrometry gave 1.7$2.0 \%$ higher concentrations than the enzymatic analyses.

Insulin was determined by radioimmunoassay with the reagents of Pharmacia, Uppsala, Sweden.

\section{Derivatisation of glucose and determination by mass spectrometry}

The plasma samples $(100 \mu \mathrm{l})$ were deproteinized by mixing with $1 \mathrm{ml}$ methanol. After centrifugation, the supernatant was evaporated to dryness in a stream of nitrogen. An aldonitrile pentaacetate derivative of glucose was prepared with hydroxylamine hydrochloride in pyridine $(2.1 \mathrm{mg} / 100 \mu \mathrm{l})$ and the mixture heated at $90^{\circ} \mathrm{C}$ for $30 \mathrm{~min}$; acetic anhydride $(100 \mu \mathrm{l})$ was then added and heating continued for an additional hour. The reaction mixture was cooled, partitioned between water $(1.5 \mathrm{ml})$ and methylene chloride $(1 \mathrm{ml})$ and centrifuged. The lower methylene chloride layer was than dried in a steam of nitrogen. The extract was reconstituted with $50 \mu$ of ethyl acetate. An aliquot $(1 \mu \mathrm{l})$ of the solution was injected into the gas chromatography/ mass spectrometry system. Mass spectra were recorded on a Varian gas-liquid chromatograph/mass spectrometer-system MAT $112 \mathrm{~S}$ equipped with a $25 \mathrm{~m}$ fused silica capillary column OV-1. The column oven temperature was $220^{\circ} \mathrm{C}$. Injector block and interfaces temperature were held at $200^{\circ} \mathrm{C}$, while the ion source temperature was $22^{\circ} \mathrm{C}$. Mass spectra were recorded at an electron energy of $70 \mathrm{eV}$ and filament emission current of $0.7 \mathrm{~mA}$. Data acquisition, reduction, and selected ion monitoring were performed under software control by MAT Spectro System 200 , including peak area calculations. The peak abundance of ions $\mathrm{m} / \mathrm{z} 187$ for glucose, $\mathrm{m} / \mathrm{z} 189$ for [6,6- $\left.{ }^{2} \mathrm{H}\right]$ glucose, and $\mathrm{m} / \mathrm{z} 191$ for $\left[\mathrm{U}-{ }^{13} \mathrm{C}\right]$ glucose were monitored for calculating the plasma enrichment of the labelled glucose (16). The determination of the glucose concentrations was calibrated by primary standards. The amounts of glucose found in the certified sample SRM 909 of the National Bureau of Standards were $56.2 \pm 0.055 \mathrm{mg} / \mathrm{dl}(\mathrm{n}=7)$ and $112.7 \pm 0.97 \mathrm{mg} / \mathrm{dl}$, the target values of which were 56.4 and $112.8 \mathrm{mg} / \mathrm{dl}$. The precision of glucose determination in plasma by isotope dilution mass spectrometry showed coefficients of variation of 0.86 to $0.99 \%$ $(\mathrm{n}=14)$

Determination of glucose turnover rate with $\left[6,6-{ }^{2} H\right]$ glucose Basal conditions

The test was started at 7:45 a.m. after a $12 \mathrm{~h}$ overnight fast of the test persons. After weighing, an i.v. canule was inserted into the left and right forearm, one for the application of the substrates and the other for drawing blood samples.

Thirty minutes later, the first blood sample was drawn. The concentrations of glucose, glucagon, catecholamines, cortisol, growth hormone, and insulin were measured in the plasma. 
Following the blood sampling a bolus of $\left[6,6-{ }^{2} \mathrm{H}\right]$ glucose $(10$ $\mathrm{mg} / \mathrm{kg}$ ) was injected; additionally, a perfusor was started for the continuous infusion of $\left[6,6-{ }^{2} \mathrm{H}\right]$ glucose $(50-250 \mu \mathrm{g} / \mathrm{kg}$ $\times$ min). To determine the enrichment of the isotope, blood samples were taken twice after 45 minutes, and thereafter every 30 minutes.

\section{Euglycaemic-hyperinsulinaemic clamp (1)}

The procedure was the same as described under "basal conditions" with the following modifications. After the first blood sampling and the bolus injection of labelled glucose, an insulin infusion (Velasulin $\mathrm{H}$ ) was started at a rate of $800 \mathrm{mIU} / \mathrm{min}$ for the first 10 minutes and then at a rate of $1.0 \mathrm{mIU} / \mathrm{kg} \times \mathrm{min}$. The glucose infusion, a mixture of native and labelled glucose, was started 5 minutes later. The glucose concentration in blood was kept constant at a mean level of $80 \mathrm{mg} / \mathrm{dl}$. The appropriate glucose infusion rates were determined according to l.c. (1).

Blood glucose levels were measured every five minutes. The determination of isotope enrichment and insulin was performed in the same way as under basal conditions.

The insulin infusion was stopped after 330 minutes whereas the glucose infusion was continued for another 10 minutes to avoid hypoglycaemia.

Determination of the turnover and oxidation rate with $\left[\mathrm{U}^{13} \mathrm{C}\right]$ glucose $(12,14,18-20)$

Test persons were prepared as described above, and the test was started at 7:45 a.m. after a $12 \mathrm{~h}$ overnight fast. After weighing, the test person received an $i . v$. canule in the left and right forearm, one for the application of the substrate and one for blood sampling.

Ten minutes after inserting the i.v. canule, the first breath sample was collected into a special bag. From this bag 4 vacutainers were filled with breath gas. The same procedure was repeated after 30 minutes and these samples served as basal values of ${ }^{13} \mathrm{CO}_{2}$ enrichment in expired breath. Thirty minutes later, the first blood sample was drawn for the determination of glucose, glucagon, catecholamines, cortisol, growth hormone, and insulin. $\mathrm{NaH}^{13} \mathrm{CO}_{3}(1.0 \mathrm{mg} / \mathrm{kg} \times \mathrm{min})$ was injected for priming the $\mathrm{CO}_{2}$-pool, [U $\left.-{ }^{13} \mathrm{C}\right]$ glucose $(0.7 \mathrm{mg} / \mathrm{kg})$ was given as a bolus, and $\left[\mathrm{U}-{ }^{13} \mathrm{C}\right]$ glucose $(20 \mu \mathrm{g} / \mathrm{kg} \times \mathrm{min})$ was continuously infused.

After 60 minutes and again at 120 minutes blood samples were taken to determine the isotope enrichment in blood. In parallel the expired breath was collected and transfered to vacutainers for determination of ${ }^{13} \mathrm{CO}_{2}$ enrichment. Thereafter blood samples were taken and expired breath collected every 30 minutes for 300 minutes, and then every 15 minutes. Glucagon, catecholamines, and insulin were measured at 210 minutes and at the end of the test $(420 \mathrm{~min})$.

${ }^{13} \mathrm{C}$-isotope abundance $\left({ }^{13} \mathrm{C} \%\right.$ ) is expressed as the per mil relative difference from the reference standard, Pee Dee Belemnite (PDB) Limestone (South Carolina). The percentage of ${ }^{13} \mathrm{C}$ in the PDB-Standard is higher than in organic carbon of the biosphere. Hence, the ${ }^{13} \mathrm{C}$-values of organic carbon have a negative value on the PDB-scale.

Only $81 \%$ of the metabolically generated ${ }^{13} \mathrm{CO}_{2}$ is recovered in the expired breath (18). The reason for this finding is not known, but it has to be taken into account when calculating oxidation rates.

The oxidation rate of glucose, calculated from ${ }^{13} \mathrm{CO}_{2}$ in the expired breath, was determined by a sensitive mass spectrometer (isotope ratio mass spectrometer, IRMS Delta E). This procedure requires only very small amounts of $\left[\mathrm{U}-{ }^{13} \mathrm{C}\right]$ glucose. The
Breath Gas Analysis System analyses the breath samples automatically thus enabling $40-60{ }^{13} \mathrm{CO}_{2}$ analyses per day.

The turnover rate of glucose, determined by isotope dilution of $\left[\mathrm{U}-{ }^{13} \mathrm{C}\right]$ glucose, gave results between 1.9 and $2.2 \mathrm{mg} / \mathrm{kg}$ $\times$ min. These data are lower than those with $\left[6,6-{ }^{2} \mathrm{H}\right]$ glucose, because the label is partly recycling in the gluconeogenic pathway.

\section{Calculations}

From the enrichment of labelled glucose under steady-state conditions the rate of appearance can be calculated. The calculations were performed according to the following formulae $(12-15,21)$.

\section{Enrichment of isotopes (atom percent excess, APE)}

$$
\mathrm{APE}=\frac{\left[6,6-{ }^{2} \mathrm{H}\right] \text { glucose }(\mathrm{g} / \mathrm{l})}{\text { glucose }(\mathrm{g} / \mathrm{l})+\left[6,6-^{-2} \mathrm{H}\right] \text { glucose }(\mathrm{g} / \mathrm{l})} \times 100
$$

\section{Turnover rate of glucose $\left(\mathrm{R}_{\mathrm{a}}\right)$}

Under steady-state conditions: rate of appearance $\left(R_{a}\right)=$ rate of disappearance $\left(R_{d}\right)$

$$
\mathrm{R}_{\mathrm{a}}(\mathrm{mg} / \mathrm{kg} \times \min )=\frac{\mathrm{APE}_{\mathrm{i}}}{\mathrm{APE}_{\mathrm{p}}} \times \mathrm{F}
$$

$\mathrm{APE}_{\mathrm{i}} \rightarrow$ APE of the infused solution

$\mathrm{APE}_{\mathrm{p}} \rightarrow$ APE of the blood plasma

$\mathrm{F} \quad \rightarrow$ infusion rate of labelled glucose $(\mathrm{mg} / \mathrm{kg} \times \mathrm{min})$

\section{Glucose clearance}

$$
\begin{aligned}
& \operatorname{MR}(\mathrm{ml} / \mathrm{kg} \times \mathrm{min})= \\
& \frac{\mathrm{R}_{\mathrm{a}}(\mathrm{mg} / \mathrm{kg} \times \mathrm{min})}{\text { glucose concentration in plasma }(\mathrm{mg} / \mathrm{ml})} \\
& \text { Recycling of glucose } \\
& \text { Glucose recycling }(\%)= \\
& \frac{\mathrm{R}_{\mathrm{a}}\left(\left[6,6-{ }^{2} \mathrm{H}\right] \text { glucose }\right)-\mathrm{R}_{\mathrm{a}}\left(\left[\mathrm{U}-{ }^{13} \mathrm{C}\right] \mathrm{glucose}\right) \times 100}{\mathrm{R}_{\mathrm{a}}\left(\left[6,6-{ }^{2} \mathrm{H}\right] \text { glucose }\right)}
\end{aligned}
$$

Glucose oxidation rate $\left(\left[\mathrm{U}-{ }^{13} \mathrm{C}\right]\right.$ glucose)

$\% \mathrm{CO}_{2}$ from glucose oxidation =

$\left[{ }^{13} \mathrm{C}\right]$ enrichment in breath $(\%) \times 100$

$\left[{ }^{13} \mathrm{C}\right]$ enrichment in plasma glucose $(\%) \times 0.81$

$0.81 \rightarrow$ empirical factor according to Allsop et al. (18)

Glucose oxidation rate $=$

$$
\% \mathrm{CO}_{2} \text { from glucose } \times \frac{\mathrm{VCO}_{2}}{6} \times 0.180
$$

$\mathrm{VCO}_{2} \rightarrow \mu \mathrm{mol}$ expired $\mathrm{CO}_{2}$ per kg body weight per minute $6 \rightarrow 1 \mathrm{~mol}$ glucose delivers $6 \mathrm{~mol} \mathrm{CO}_{2}$ $0.18 \rightarrow 1 \mu \mathrm{mol}$ glucose $=0.180 \mathrm{mg}$ glucose

The hepatic glucose production rate (HPR) is the difference between the rate of appearance of glucose and the glucose infusion rate $(\mathrm{GIR})$ :

$\operatorname{HPR}(\mathrm{mg} / \mathrm{kg} \times \mathrm{min})=\mathrm{R}_{\mathrm{a}}-\mathrm{GIR}$

All calculations are based on mean values of time periods of at least 30 minutes under steady-state conditions. 


\section{Subjects}

All volunteers had to sign a written consent after having been informed about the procedures of the study. All subjects were healthy, of normal body weight, receiving no medications and with no family history of diabetes mellitus. They were aged $22-30$ years.

\section{Statistics}

The results are expressed as arithmetic mean \pm standard deviation and the correlations were calculated using Student's ttest for independent groups; $\mathrm{p}<0.05$ was assumed to be statistically significant.

\section{Results}

Twenty six measurements of the glucose turnover rate were performed in order to test variations of the $[6,6-$ $\left.{ }^{2} \mathrm{H}\right]$ glucose batches, the size of the bolus and the infusion rate. The degree of purity of the labelled glucose samples was a primary problem. Some batches gave cloudy solutions and had to be eliminated. Heat sterilization at an unsuitable $\mathrm{pH}$ resulted in brownish solutions, and the analysed concentrations and calculated results were inconsistent.

The turnover rates were determined quantitatively under steady-state conditions. An early constant enrichment of labelled glucose in the blood was achieved by priming injections of the tracer glucose (fig. 1,2).

Evaluation of different experiments suggested a priming dose for $\left[6,6{ }^{2} \mathrm{H}\right]$ glucose of $400-600 \mathrm{mg}$ and for $\left[\mathrm{U}-{ }^{13} \mathrm{C}\right.$ ]glucose of about $94 \mathrm{mg}$. The infusion rates for $\left[6,6-{ }^{2} \mathrm{H}\right]$ glucose and $\left[\mathrm{U}-{ }^{13} \mathrm{C}\right]$ glucose had to be adapted to the sensitivity of the mass spectrometer used for the determination of isotope enrichment. Under our conditions the appropriate infusion rate for [6,6${ }^{2} \mathrm{H}$ ]glucose was $50 \mu \mathrm{g} / \mathrm{kg} \times \min$ and for [U${ }^{13} \mathrm{Clglucose} 20 \mu \mathrm{g} / \mathrm{kg} \times \mathrm{min}$.

Glucose utilization rates under basal conditions, determined with $\left[6,6-{ }^{2} \mathrm{H}\right]$ glucose and $\left[\mathrm{U}-{ }^{13} \mathrm{C}\right]$ glucose, are shown in table 2. Since the label of the metabolized $\left[\mathrm{U}-{ }^{13} \mathrm{C}\right]$ glucose may reappear due to gluconeogenesis,

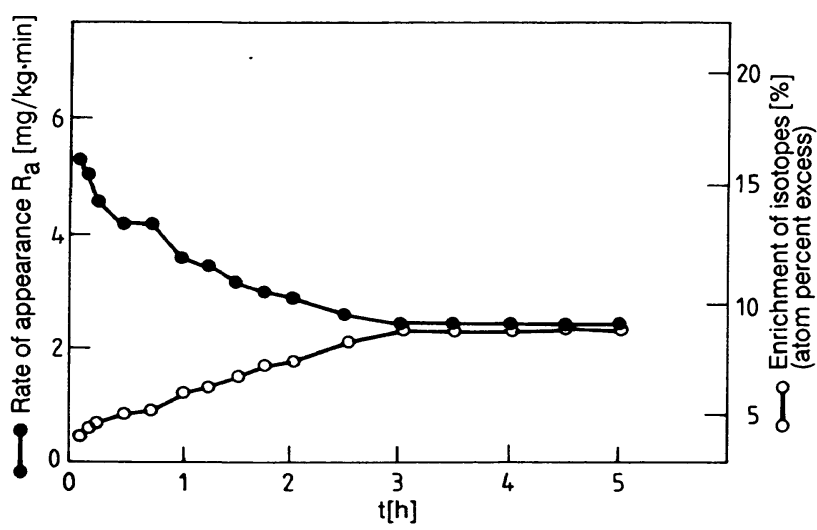

Fig. 1. Enrichment of $\left[6,6-{ }^{2} \mathrm{H}\right]$ glucose in blood (APE, atom percent excess) and the glucose disposal rate in a healthy volunteer. The steady-state was reached after $180 \mathrm{~min}$. Bolus: $1600 \mathrm{mg}$; infusion rate of $\left[6,6{ }^{2} \mathrm{H}\right]$ glucose: 205 $\mu \mathrm{g} / \mathrm{kg} \times \min$.

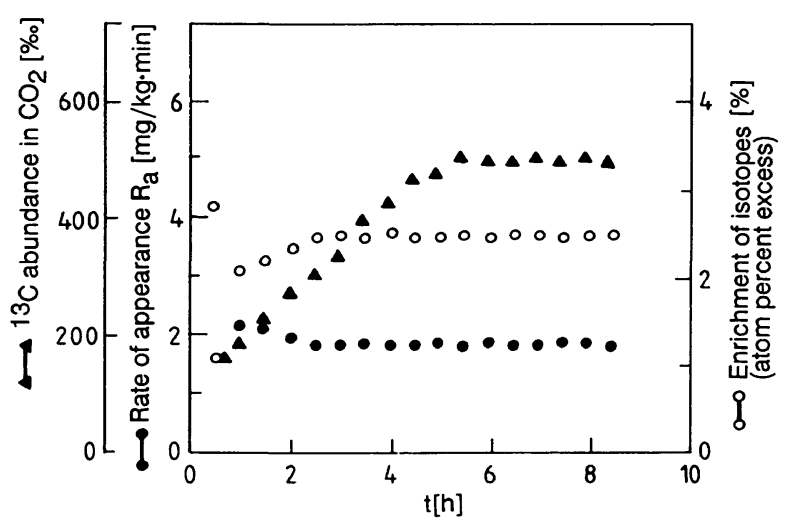

Fig. 2. Glucose turnover and glucose oxidation rates determined with $\left[\mathrm{U}^{-13} \mathrm{C}\right]$ glucose. Atom percent excess of $[\mathrm{U}$ ${ }^{13} \mathrm{C}$ glucose, the glucose disposal rate $\left(\mathrm{R}_{\mathrm{a}}\right)$, and the abundance of ${ }^{13} \mathrm{CO}_{2}$ in the expired breath are shown. In the expired breath, the ${ }^{13} \mathrm{CO}_{2}$ enrichment attains a steadystate only after 5 hours: Healthy volunteer: bolus of $\mathrm{NaH}^{13} \mathrm{CO}_{3}$ : $70 \mathrm{mg}$; [U- $\left.{ }^{13} \mathrm{C}\right]$ glucose: $120 \mathrm{mg}$. Glucose infusion rate: $50 \mu \mathrm{g} / \mathrm{kg} \times \mathrm{min}$.

the rate of appearance $\left(R_{a}\right)$ values determined with this tracer were lower (recycling). Under our experimental conditions, the extent of recycling of glucose was about $25 \%$. At the same time the oxidation rates of glucose were between 0.8 and $1.2 \mathrm{mg} / \mathrm{kg} \times \mathrm{min}$.

Tab. 2. Different parameters of the glucose turnover rate of healthy volunteers under basal conditions.

\begin{tabular}{llll}
\hline & Parameters & $\mathrm{n}$ & Results \\
\hline 1 & $\begin{array}{l}\text { Glucose turnover rate } \\
\left(\left[6,6-{ }^{2} \mathrm{H}\right] \text { glucose) }\right.\end{array}$ & 8 & $2.42 \pm 0.11 \mathrm{mg} / \mathrm{kg} \times \mathrm{min}$ \\
2 & $\begin{array}{l}\text { Glucose turnover rate } \\
\left(\left[\mathrm{U}{ }^{13} \text { C]glucose) }\right.\right.\end{array}$ & 4 & $1.82 \pm 0.03 \mathrm{mg} / \mathrm{kg} \times \mathrm{min}$ \\
3 & Glucose oxidation rate & 4 & $1.34 \pm 0.17 \mathrm{mg} / \mathrm{kg} \times \mathrm{min}$ \\
4 & Glucose clearance & 8 & $3.04 \pm 0.17 \mathrm{ml} / \mathrm{kg} \times \mathrm{min}$ \\
5 & Glucose recycling & 4 & $0.60 \mathrm{mg} / \mathrm{kg} \times \mathrm{min}=24,7 \%$ \\
6 & Hepatic glucose production & 8 & $2.21 \pm 0.08 \mathrm{mg} / \mathrm{kg} \times \mathrm{min}$ \\
\hline
\end{tabular}


Tab. 3. Comparison of glucose turnover rates as measured by glucose infusion rates during euglycaemic-hyperinsulinaemic clamp conditions, and glucose turnover rates using $\left[6,6-{ }^{2} \mathrm{H}\right]$ glucose.

\begin{tabular}{|c|c|c|c|c|c|}
\hline & Argoud et al. (2) & McMahon et al. (26) & Own resul & & \\
\hline $\begin{array}{l}\text { 1. Glucose infusion rate } \\
(\mathrm{mg} / \mathrm{kg} \times \mathrm{min})\end{array}$ & $8.0 \pm 0.4$ & $9.8 \pm 0.6$ & 9.6 & 9.46 & 9.0 \\
\hline $\begin{array}{l}\text { 2. } \begin{array}{l}\mathrm{R}_{\mathrm{a}}\left(\left[6,6-{ }^{2} \mathrm{H}\right] \text { glucose }\right) \\
(\mathrm{mg} / \mathrm{kg} \times \mathrm{min})\end{array}\end{array}$ & $6.7 \pm 0.5$ & $7.6 \pm 0.5$ & 8.3 & 9.52 & 9.23 \\
\hline $\begin{array}{l}\text { 3. Relative difference } \\
\text { between } 1 \text {. and } 2 \text {. }\end{array}$ & $-17 \pm 0.02 \%$ & $-22.4 \%$ & $-13.5 \%$ & $+1.7 \%$ & $+2.5 \%$ \\
\hline
\end{tabular}

Under euglycaemic-hyperinsulinaemic conditions the glucose turnover rate increased up to about $9 \mathrm{mg} / \mathrm{kg}$ $\times$ min. In the first experiments we determined the turnover rate of glucose under basic conditions, and then increased the insulin concentration up to $80 \mathrm{mU} / 1$ while the glucose concentration was held constant at $80-90 \mathrm{mg} / \mathrm{dl}$ by glucose infusion. Since under the conditions of the euglycaemic-hyperinsulinaemic clamp the new steady-state was attained only after an additional 3-4 hours, the total experiment lasted about 8 hours (17). A turnover rate of glucose of 9.52 $\mathrm{mg} / \mathrm{kg} \times \mathrm{min}$ was calculated during the same time period during that $9.46 \mathrm{mg}$ glucose $/ \mathrm{kg} \times \min$ were infused. Because of the long experimental period the euglycaemic-hyperinsulinaemic clamp studies were performed separately on different days (fig. 3). In some experiments "negative hepatic glucose production rates" were calculated, because the glucose
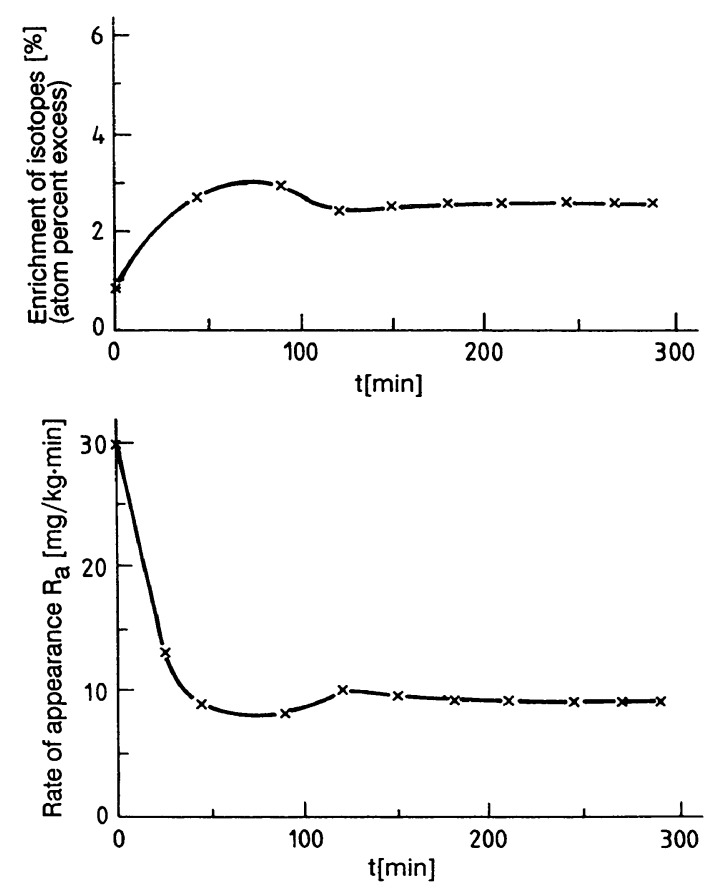

Fig. 3. Euglycaemic-hyperinsulinaemic clamp. Course of atom percent excess (APE) and the measured glucose turnover. Healthy volunteer: $72 \mathrm{~kg}$, height $1.78 \mathrm{~m}$. Bolus: $720 \mathrm{mg}\left[6,6-{ }^{2} \mathrm{H}\right]$ glucose. Infusion rate of $\left[6,6{ }^{2} \mathrm{H}\right]$ glucose: $100 \mu \mathrm{g} / \mathrm{kg} \times \mathrm{min}$. infusion rates were higher than the calculated rates of appearance $R_{a}$ (tab. 3). This apparent underestimation of the glucose turnover rate occurred if steadystate conditions were not established. This was avoided when the infused glucose contained the tracer glucose in a constant ratio. Furthermore the calculations of rate of appearance $R_{a}$ should be based on several subsequent measurements of enrichment of isotopes (atom percent excess, APE) in the blood.

\section{Discussion}

The analysis of the turnover rates of glucose allows a more dynamic view of the metabolism in vivo under normal and pathological conditions. In these experiments the required amount of labelled substrates depends on the sensitivity of the mass spectrometer. Furthermore certain experimental conditions must be fulfilled in order to obtain reliable measurements of the turnover rates. Some of these consitions are listed in table 4.

Tab. 4. Main assumptions for turnover measurements with the isotope dilution method.

1. The metabolism of native and labelled glucose is identical in all metabolic pathways and under all conditions (no isotope effect).

2. There is no labelled contaminant of the $\left[6,6-{ }^{2} \mathrm{H}\right]$ glucose which may accumulate in the blood.

3. The determinations of the atom percent excess of the labelled glucose and the glucose infusion rates are accurate and adequately precise.

4. There is one glucose pool which is labelled instantaneously and uniformly by the infused labelled glucose and which is in equilibrium with the metabolically active pool.

5. If the labelled glucose is metabolized the label does not reappear by recycling (irreversible tracer).

6. All calculations are based on steady-state conditions which reflect the real metabolic rate of glucose.

The models underlying the calculations may be inadequate and they should be adapted to the metabolic fluxes to be measured. The one-compartment model of Steele may not fit the hyperinsulinaemic condition $(23-26)$, because there may be a significant difference 
between the isotope enrichment in the blood and the metabolically active glucose pool in the tissues. Some authors (24) suggested a three-compartment model for glucose which may equilibrate with the blood glucose pool at different velocities. Our calculations are based on Steele's equation (21).

The use of adequate tracers with high purity is another fundamental condition for these experiments. The purity of the tracer glucose should be checked against non-labelled glucose of the highest possible purity (Standard Reference Material, SRM). The data are based on the assumption that $\left[6,6{ }^{2} \mathrm{H}\right]$ glucose is a nonrecycling tracer and that $\left[\mathrm{U}_{-}{ }^{13} \mathrm{C}\right]$ glucose is an adequate tracer for the determination of glucose oxidation rate and glucose recycling $(7-11,26,27)$.

The turnover measurements of glucose under basal and hyperinsulinaemic conditions obtained in this study are in good agreement with the data of other authors $(12,23,26-28$; see tab. 1). But in discussing the validity of the tracers, only those experiments with the same tracer and the same experimental conditions are comparable.

Glucose utilization and hepatic glucose production rates during insulin administration were determined by the combined approach of measuring the exogenous glucose infusion rate during euglycaemic-hyperinsulinaemic clamp and the glucose disposal rate by the tracer dilution technique. Under this experimental condition the hepatic glucose production rate can be calculated as the difference between the glucose disposal rate as determined with the tracer and the infusion rate of exogenous glucose.

Since in healthy volunteers the hepatic glucose production is totally suppressed at insulin concentrations of $80-100 \mathrm{mU} / 1(28)$, the infusion rate of exogenous glucose should be identical to the turnover rate meas-

\section{References}

1. De Fronzo, R. A., Tobin, J. D. \& Andres, R. (1979) Glucose clamp technique: a method for quantifying insulin secretion and resistance. Am J. Physiol. 237, E214-E223.

2. Argoud, G. M., Schade, D. S. \& Eaton, R. P. (1987) Underestimation of hepatic glucose production by radioactive and stable tracers. Am. J. Physiol. 252, E606-E615.

3. De Fronzo, R. A., Jequier, J. E., Maeder, E., Wahren, J. \& Felber, J.-P. (1981) The effect of insulin on the disposal of intravenous glucose: results from indirect calorimetry and hepatic and femoral venous catheterization. Diabetes $30,1000-1007$.

4. De Fronzo, R. A., Simonson, D. \& Ferrannini, E. (1982) Hepatic and peripheral insulin resistance: Common feature of type 2 (non-insulin-dependent) and type 1 (insulin-dependent) diabetes mellitus. Diabetologia 23, 313-319. ured by isotope dilutions/mass spectrometry. But several authors have reported underestimations of the glucose disposal rates, measured with the tracer dilution technique $(2,26,29)$. The possible reasons for this effect have been discussed in detail $(2,8,11,26$, $27,29,30,31)$. Some of our experiments under euglycaemic-hyperinsulinaemic conditions gave negative glucose production rates as well. Therefore, the experimental conditions were carefully reexamined. The purity of the tracer glucose was reestimated but nonglucose contaminants could not be detected. According to our data the most critical point in these experiments was the steady-state of isotope enrichment under conditions of the euglycaemic-hyperinsulinaemic clamp. Since under hyperinsulinaemia the glucose space increases, there may be a different enrichment of the tracer glucose in blood and in the metabolically active glucose pools. Only long-lasting, steady-state conditions (more than $30 \mathrm{~min}$ ) may produce homogenous labelling of the tracer glucose in the different metabolic pools. According to our experience, incomplete equilibrium of glucose enrichment generates a greater variation of the results than all other factors (see 1. c. $(2,18,23,29,30))$. Therefore, in our clamp experiments exogenous glucose was mixed with labelled glucose, thus avoiding major variations of the enrichment of glucose in the blood (29).

The presented data clearly demonstrate that our experimental conditions deliver reproducible and, compared with the results of other groups, correct information on basal glucose turnover rates. Negative hepatic glucose production rates under the conditions of the euglycaemic-hyperinsulinaemic clamp were avoided by determining the glucose disposal rate under prolonged steady-state conditions. We found no isotope effects or impurities in the tracer glucose (26), and we therefore strongly argue for the further use of $\left[6,6-{ }^{2} \mathrm{H}\right]$ glucose in glucose turnover measurements.

5. De Fronzo, R. A. (1988) The triumvirate: $\beta$-cell, muscle, liver. Diabetes 37, 667-687.

6. Reaven, G. M. (1980) Insulin-independent diabetes mellitus: metabolic characteristics. Metabolism 29, 445-454.

7. Altszuler, N., Barkai, A., Bjerknes, C., Gottlieb, B. \& Steele, R. (1975) Glucose turnover values in the dog obtained with various species of labeled glucose. Am. J. Physiol. $229,1662-1667$.

8. Bier, D. M., Leak, R. D., Haymond, M. W., Arnold, K. J., Gruenke, L. D., Sperling, M. A. \& Kipnis, D. M. (1977) Measurement of "true" glucose production rates in infancy and childhood with 6,6-Dideuteroglucose. Diabetes 26, 1016- 1023 .

9. Dunn, A., Katz, J., Golden, S. \& Chenowith, M. (1976) Estimation of glucose turnover and recycling in rabbits using various $\left[{ }^{3} \mathrm{H},{ }^{14} \mathrm{C}\right]$ glucose labels. Am. J. Physiol. 230, $1159-1162$. 
10. Kalhan, S. C., Bier, D. M., Savin, S. M. \& Adam, P. A. J. (1980) Estimation of glucose turnover and ${ }^{13} \mathrm{C}$ recycling in the human newborn by simultaneous $\left[1-{ }^{13} \mathrm{C}\right]$ glucose and $\left[6,6-{ }^{2} \mathrm{H}\right]$ glucose tracers. J. Clin. Endocr. Metab. 50, 456460 .

11. Argoud, G., Schade, D. \& Eaton, P. (1985) Do stable isotopes accurately reflect glucose turnover in man? Diabetes 34, (Suppl. 1), 14A.

12. Robert, J. J., Cummins, J. C., Wolfe, R. R., Durkot, M., Matthews, D. E., Zhao, X. H. \& Bier, D. M. (1982) Quantitative aspects of glucose production and metabolism in healthy elderly subjects. Diabetes $31,203-211$.

13. Tserng, K.-Y. \& Kalhan, S. C. (1983) Calculation of substrate turnover rate in stable isotope tracer studies. Am. J. Physiol. 245, E308-E311.

14. Wolfe, R. R. (1981) Tracers in metabolic research. Radioisotope and stable isotope/mass spectrometry methods. Alan R. Liss, Inc. New York.

15. Wolfe, R. R. (1982) Stable isotope approaches for study of energy substrate metabolism. Fed. Proc. 41, 2692-2697.

16. Susanto, F. \& Reinauer, H. (1987) Gaschromatographischmassenspektrometrische Bestimmung von Glucose im Plasma unter Verwendung von Glucose- $\left[\mathrm{U}-{ }^{13} \mathrm{C}\right]$ und Glucose- $\left[6,6-{ }^{2} \mathrm{H}\right]$ als interner Standard. Lab. Med. $11,171$.

17. Reinauer, H., Susanto, F., Hübinger, A. \& Gries, F. A. (1989) Umsatzmessungen der Glucose unter normo- und hyperinsulinämischen Bedingungen. Beitr. Infusionther. 25, $399-411$

18. Allsop, J. R., Wolfe, R. R. \& Burke, J. F. (1978) Tracer priming of the bicarbonate pool. J. Appl. Physiol. 45, 137139.

19. Ghoos, Y., Rutgeerts, P., Vantrappen, G. \& Hiele, M. (1988) Measurement of ${ }^{13} \mathrm{C}$-glucose oxidation rate using mass spectrometric determination of the $\mathrm{CO}_{2}: \mathrm{Ar}$ ratio and spirometry. Biomed. Environm. Mass. Spectr. 15, 447-451.

20. Schoeller, D. A., Klein, P. D., Watkins, J. B., Heim, T. \& McLean, jr. M. C. $(1980){ }^{13} \mathrm{C}$-abundances of nutritients and the effect of variations in ${ }^{13} \mathrm{C}$ isotopic abundances of test meals formulated for ${ }^{13} \mathrm{CO}_{2}$ breath test. Am. J. Clin. Nutr. $33,2375-2385$

21. Steele, R., Wall, J. S., De Bodo, R. C. \& Altszuler, N. (1956) Measurement of size and turnover rate of body glucose pool by the isotope dilution method. Am. J. Physiol. $187,15-24$.
22. Steele, R., Rostami, H. \& Altszuler, N. (1974) A twocompartment calculator for the dog glucose pool in nonsteady state. Fed. Prod. 33, 1839-1876.

23. Cobelli, C., Mari, A. \& Ferrannini, E. (1987) Non-steady state: error analysis of Steele's model and developments for glucose kinetics. Am. J. Physiol. 252, E679-E689.

24. Ferrannini, E., Smith, J. D., Cobelli, C., Toffolo, G., Pilo, A. \& De Fronzo, R. A. (1985) Effect of insulin on the distribution and disposition of glucose in man. J. Clin. Invest. $76,357-364$.

25. Finegood, D. T., Bergmann, R. M. \& Vranic, M. (1987) Estimation of endogenous glucose production during hyperinsulinemic-euglycemic glucose clamps. Diabetes 36 , 914-924.

26. McMahon, M. M., Schwenk, W. F., Haymond, M. W. \& Rizza, R. A. (1989) Underestimation of glucose turnover measured with $\left[6-{ }^{3} \mathrm{H}\right]-$ and $\left[6,6-{ }^{2} \mathrm{H}\right]-$ but not with $\left[6-{ }^{14} \mathrm{C}\right]$ glucose during hyperinsulinemia in humans. Diabetes 38 , 97-107.

27. Bell, P. M., Firth, R. G. \& Rizza, R. A. (1986) Assessment of insulin action in insulin-dependent diabetes mellitus using $\left[6-{ }^{14} \mathrm{C}\right]$ glucose, $\left[3-{ }^{3} \mathrm{H}\right]$ glucose and $\left[2-{ }^{3} \mathrm{H}\right]$ glucose. J. Clin. Invest. $78,1479-1486$.

28. Rizza, R. A., Mandarino, L. J. \& Gerich, J. E. (1981) Doseresponse characteristics for effects of insulin on production and utilization of glucose in man. Am. J. Physiol. 240, E630-E639.

29. Yki-Järvinen, H., Consoli, A., Nurjhan, N., Young, A. A \& Gerich, J. E. (1989) Mechanism for underestimation of isotopically determined glucose disposal. Diabetes 38 , $744-751$.

30. Radziuk, J., Norwich, K. H. \& Vranic, M. (1978) Experimental validation of measurement of glucose turnover in non-steady state. Am. J. Physiol. 234, E84-E93.

31. Schwenk, W. F., Butler, P., Haymond, M. W. \& Rizza, R. A. (1988) Underestimation of glucose turnover corrected with HPLC purification of tritiated glucose. Diabetes 37, (Suppl. 1) 82A.

Prof. Dr. med. H. Reinauer

Lehrstuhl für klinische Biochemie

Diabetes-Forschungsinstitut

Auf'm Hennekamp 65

D-4000 Düsseldorf 
